\title{
Residual feed intake in beef cattle
}

\author{
J P.F. Arthur ${ }^{1}$ and R.M. Herd ${ }^{2}$
}

\begin{abstract}
${ }^{1}$ Elizabeth Macarthur Agricultural Institute, NSW Department of Primary Industries, Camden NSW 2570, Australia ${ }^{2}$ Beef Industry Centre, NSW Department of Primary Industries, University of New England, Armidale NSW 2351 , Australia
\end{abstract}

ABSTRACT - Providing feed is a major input cost in beef production, hence improvements in the efficiency of feed utilisation will reduce the cost of production. Residual feed intake (RFI) is a measure of feed efficiency, and is defined as the difference between an animal's actual feed intake and its expected feed intake based on its size and growth. It is independent of the level of production, and the lower the value the more efficient the animal is. This paper examines the current state of knowledge on RFI. Available information indicates that postweaning RFI is moderately heritable, and that selection for low RFI will result in progeny that consume less feed for the same level of production as progeny of high RFI cattle. Under ad libitum feeding, RFI is phenotypically independent of growth traits. There is a weak genetic relationship between RFI and fatness but additional studies are needed to assess the magnitude of this relationship in different breeds, sexes, ages and feeding regimes. Residual feed intake is believed to represent inherent variation in basic metabolic processes which determine efficiency. Economic analyses of genetic improvement schemes that incorporate testing of individuals for RFI have yielded substantial economic benefits over and above existing schemes that do not include RFI testing. Selection for low RFI has an additional benefit of reducing greenhouse gas emissions by cattle.

Key Words: cattle, feed efficiency, growth, residual feed intake

\section{Introduction}

Profitability of production is dependent on both inputs and outputs. Providing feed to animals is a major input cost in most animal production systems. This has long been recognized in the pig and poultry industries, in which cost of feed is easily quantified. These industries have made significant improvements in feed efficiency through both genetic and non-genetic means. Although the cost of providing feed to grazing animals is more difficult to quantify, it is still a major cost of production in the extensive grazing industries. Improvement in the efficiency of feed utilisation will help reduce the cost of production. Measuring individual animal feed intake is difficult and expensive. Recent advances in computing and electronics, and availability of reliable automatic feed intake recorders have made it easier to measure feed intake.

In many beef production systems a large proportion (65 - 85\%; Montaño-Bermudez et al., 1990) of the feed is used by the cow breeding herd, while young growing animals consume feed which is often of higher value. In the past, most studies on feed efficiency have concentrated on young growing cattle, with little emphasis placed on the cow herd, where maintenance requirements are most important. Feed cost for maintenance is estimated to represent at least 60 to $65 \%$ of the total feed requirements for the cow herd, with considerable variation among individual animals independent of body size (MontañoBermudez et al., 1990). It is therefore important that the efficiency of feed utilisation of the whole production system is considered in order to improve enterprise profitability. Residual feed intake (RFI) is a measure of feed efficiency which seeks to capture some of this variation in maintenance requirements. The objective of this paper is to review recent research findings on RFI and highlight the challenges and barriers of its use in genetic improvement of beef cattle.

\section{Measures of feed efficiency}

The utilization of the feed consumed by an animal involves a complex of biological processes and interactions with the environment. In addition, it is 
complicated by the fact that feed intake is highly correlated with body size and level of production. To overcome these complexities and to relate feed intake to production system efficiency, several measures of feed efficiency have been developed and used, as described in detail by Archer et al. (1999). They can be grouped into: gross efficiency, partial efficiency of growth, maintenance efficiency, cow/calf efficiency and RFI. In young beef cattle, feed efficiency is usually evaluated in relation to growth, and some of the most common measures used are: partial efficiency of growth, feed conversion ratio (FCR) and RFI. The definitions and computational formulae for these growth and feed efficiency traits are given in Table 1. Phenotypic and genetic correlations among most of these measures of feed efficiency are high. However, there are differences between these measures of feed efficiency in their relationships with other traits, such as growth traits, as reported by Arthur et al. (2001b).

\section{Residual feed intake}

In beef cattle, the concept of residual feed intake (RFI) was first used by Koch et al. (1963), who examined a number of indices for calculating efficiency which recognised that differences in both weight maintained and weight gain affect feed requirements in growing cattle. Koch et al. (1963) suggested that feed intake could be adjusted for body weight and weight gain (or any other production trait or energy sink identified), effectively partitioning feed intake into 2 components: (1) the feed intake expected for the given level of production; and (2) a residual portion. The residual portion of feed intake can be used to identify animals which deviate from their expected feed intake, with efficient animals having lower (negative) RFI values. Residual feed intake is therefore defined as the difference between an animal's actual feed intake and its expected feed intake based on its size and growth over a specified period. The computation of RFI requires the estimation of expected feed intake. This can be predicted (Table 1) from production data by using feeding standards formulae (e.g. NRC, 1996), or by regression using actual feed test data (Kennedy et al., 1993; Arthur et al., 2001b). Although the genetic correlations among the different forms of RFI may be high, their relationships with other traits may be different (Arthur et al., 2001b).

Table 1. Definition of growth and feed efficiency traits

\begin{tabular}{|c|c|c|c|}
\hline Trait name & Abbreviation & Definition & Formula \\
\hline Liveweight & LWT & $\begin{array}{l}\text { Weight (wt) at a } \\
\text { specified age }\end{array}$ & \\
\hline $\begin{array}{l}\text { Average } \\
\text { daily gain }\end{array}$ & ADG & Wt gain per day & $\begin{array}{l}\text { Regression } \\
\text { coefficient } \\
\text { from the } \\
\text { regression of } \\
\text { weight on time } \\
\text { (days) }\end{array}$ \\
\hline $\begin{array}{l}\text { Relative } \\
\text { growth rate }\end{array}$ & RGR & $\begin{array}{l}\text { Growth relative } \\
\text { to instantaneous } \\
\text { size. Expressed } \\
\text { in this study as } \\
\text { percentage of } \\
\text { change in LWT } \\
\text { per day }\end{array}$ & $\begin{array}{c}100 \times \text { x (log end } \\
\text { wt }- \text { log start } \\
\text { wt) } \div \text { days on } \\
\text { test (Fitzhugh } \\
\& \text { Taylor, } \\
1971 \text { ) }\end{array}$ \\
\hline Kleiber ratio & KR & $\begin{array}{l}\text { Wt gain per unit } \\
\text { metabolic body } \\
\text { wt }\end{array}$ & $\begin{array}{c}\text { ADG } \div \text { average } \\
\text { test period } \\
\mathrm{LWT}^{0.75}\end{array}$ \\
\hline Feed intake & FI & $\begin{array}{l}\text { Feed intake per } \\
\text { day }\end{array}$ & \\
\hline $\begin{array}{c}\text { Feed } \\
\text { conversion } \\
\text { ratio }\end{array}$ & FCR & $\begin{array}{l}\text { FI per unit wt } \\
\text { gain }\end{array}$ & $\mathrm{FI} \div \mathrm{ADG}$ \\
\hline $\begin{array}{c}\text { Partial } \\
\text { efficiency of } \\
\text { growth }\end{array}$ & PEG & $\begin{array}{l}\text { Efficiency of wt } \\
\text { gain net of } \\
\text { maintenance } \\
\text { feed (Fm) } \\
\text { requirements }\end{array}$ & $\begin{array}{l}\text { ADG } \div(\mathrm{FI}- \\
\text { Fm), where Fm } \\
\text { was obtained } \\
\text { by formulas } \\
\text { from feeding } \\
\text { standards (eg. } \\
\text { NRC, 1996) }\end{array}$ \\
\hline $\begin{array}{l}\text { Residual } \\
\text { feed intake } \\
\text { (by Feeding } \\
\text { Standards } \\
\text { formulae) }\end{array}$ & $\mathrm{RFI}_{\mathrm{fsf}}$ & $\begin{array}{l}\text { FI net of the } \\
\text { expected feed } \\
\text { requirements for } \\
\text { maintenance and } \\
\text { growth, with the } \\
\text { expected feed } \\
\text { requirements } \\
\text { (expFI) obtained } \\
\text { from feeding } \\
\text { standards } \\
\text { formula }\end{array}$ & $\begin{array}{c}\text { FI - expFI, } \\
\text { where expFI } \\
\text { was obtained } \\
\text { by formulas } \\
\text { from feeding } \\
\text { standards (eg. } \\
\text { NRC, 1996) }\end{array}$ \\
\hline $\begin{array}{l}\text { Residual } \\
\text { feed intake } \\
\quad \text { (by } \\
\text { Regression) }\end{array}$ & $\mathrm{RFI}_{\mathrm{reg}}$ & $\begin{array}{l}\text { FI net of the } \\
\text { expected feed } \\
\text { requirements for } \\
\text { maintenance and } \\
\text { growth, with } \\
\text { expFI obtained } \\
\text { by regression }\end{array}$ & $\begin{array}{l}\text { FI - expFI, } \\
\text { where expFI } \\
\text { was obtained } \\
\text { by the } \\
\text { regression of FI } \\
\text { on average test } \\
\text { period LWT } \\
\text { and ADG }\end{array}$ \\
\hline
\end{tabular}


For this paper, only data from RFI computed by regression will be used, as this procedure makes RFI phenotypically independent of the production traits used to calculate expected feed intake, and so allows comparison between individuals differing in level of production during the measurement period. The independence of RFI from production has led some authors to suggest that RFI may represent inherent variation in basic metabolic processes which determine efficiency (Brelin \& Brannang, 1982; Korver, 1988). Feed conversion ratio, defined as feed intake per unit gain in weight, has traditionally been used as a measure of feed efficiency, and will be used occasionally as comparison to RFI in this paper. For both traits, efficient animals have lower values relative to inefficient animals.

\section{Testing cattle for residual feed intake}

Testing cattle for RFI requires the measurement of feed intake and growth over a defined period of time. Feed intake and its utilization by cattle involve a complex of biological processes and interactions with the environment. In order to be able to compare test results across time and across location, as required for genetic analyses, for example, it is important to control as much as possible, those factors that affect feed intake and its utilization. These factors include; age at start of test, sex of cattle, diet composition and testing procedures. Results from recent studies on the duration of test and frequency of measurement (Archer et al., 1997; Wang et al., 2006) have formed the basis for developing standard test protocols.

In Australia, a Standards Manual for testing cattle for RFI, developed in 1999 is used for all RFI tests. This ensures that data from tests conducted at different times in the year and at different locations can be accepted for genetic improvement. The manual, which was revised in 2001, outlines protocols and procedures to use. These cover eligibility of cattle (age, sex etc), conduct of test, data processing, and accreditation of test stations. A copy of the Standards Manual can be obtained from:

www.dpi.nsw.gov.au/agriculture/livestock/beef/b reeding/general/feed-efficiency.

\section{Genetics of residual feed intake}

\section{Genetic parameters}

A summary of the genetic parameters, from recent studies, for RFI and its relationships with other economically important traits are presented in Table 2. The pre-1999 information reviewed by Archer et al. (1999) and the post-2000 information presented in Table 2, indicates that both RFI and FCR have moderate heritability, similar to that of growth rate. Residual feed intake is correlated with FCR, with reported genetic correlation coefficients ranging from 0.45 to 0.85 . This implies that genetic improvement in RFI will result in a correlated improvement in FCR (Arthur et al., 2001a,b; Schenkel et al., 2004; Robinson \& Oddy, 2004; Hoque et al., 2006a; Nkrumah et al., 2007a). As expected, there is a positive correlation between RFI and feed intake indicating that more efficient (with low RFI) cattle consume less feed. Residual feed intake, by definition, is phenotypically independent of the production traits (ADG and metabolic weight) used in its calculation. It has been asserted that this relationship might not apply at the genetic level (Kennedy et al., 1993). The close to zero correlations (when the standard errors are taken into consideration) between RFI and ADG and metabolic weight indicates that this relationship holds at the genetic level as well. Genetic correlations between RFI and other growth traits (except yearling fat depth) are also close to zero. In the report by Arthur et al. (2001a), the genetic effects for weaning and yearling weights were partitioned into direct and maternal additive effects. However, the net (not partitioned) effects of the correlations were close to zero, after taking into account the magnitude of the standard errors and the opposing signs for the direct and maternal effects in that study. Although the number of reports available is limited, it appears that postweaning RFI is also genetically independent of mature cow weight (Herd \& Bishop, 2000; Archer et al., 2002; Arthur et al., 2005). In contrast, the genetic correlation between postweaning FCR and ADG is reported to be moderate and negative in most studies (Arthur et al., 2001a,b; Schenkel et al., 2004). This indicates that animals selected for low FCR (more efficient) are likely to produce progeny with high mature weight, resulting in high maintenance cost in breeding cows. 
Table 2 - Heritability estimates and genetic correlations ( \pm standard error) between postweaning residual feed intake (RFI) and other economically important traits in beef cattle

\begin{tabular}{|c|c|c|c|c|c|c|c|}
\hline \multirow[b]{2}{*}{ Traits } & \multicolumn{7}{|c|}{ Breed and source ${ }^{A}$ of information } \\
\hline & $\begin{array}{c}\text { Hereford } \\
\text { (Source-1) }\end{array}$ & $\begin{array}{c}\text { Angus } \\
\text { (Source-2) }\end{array}$ & $\begin{array}{l}\text { Charolais } \\
\text { (Source-3) }\end{array}$ & $\begin{array}{c}\text { Mixed } \\
\text { (Source-4) }\end{array}$ & $\begin{array}{c}\text { Mixed } \\
\text { (Source-5) }\end{array}$ & $\begin{array}{c}\text { Wagyu } \\
\text { (Source-6) }\end{array}$ & $\begin{array}{c}\text { Composites } \\
\text { (Source-7) }\end{array}$ \\
\hline $\begin{array}{c}\text { No. of animals } \\
\text { Heritability }\end{array}$ & 540 & 1180 & 792 & 1481 & 2284 & 740 & 464 \\
\hline RFI & $0.16 \pm 0.08$ & $0.39 \pm 0.03$ & $0.39 \pm 0.04$ & $0.18 \pm 0.06$ & $0.38 \pm 0.07$ & $0.24 \pm 0.11$ & $0.21 \pm 0.12$ \\
\hline Feed conversion ratio & $0.17 \pm 0.09$ & $0.29 \pm 0.04$ & $0.46 \pm 0.04$ & $0.06 \pm 0.04$ & $0.37 \pm 0.06$ & $0.15 \pm 0.04$ & $0.41 \pm 0.15$ \\
\hline \multicolumn{8}{|c|}{ Genetic correlations with RFI } \\
\hline Feed intake & $0.64 \pm 0.16$ & $0.66 \pm 0.05$ & $0.79 \pm 0.04$ & $0.43 \pm 0.15$ & 0.81 & $0.78 \pm 0.06$ & $0.73 \pm 0.18$ \\
\hline ADG & $0.09 \pm 0.29$ & $-0.04 \pm 0.08$ & $-0.10 \pm 0.13$ & $0.09 \pm 0.20$ & 0.01 & $0.25 \pm 0.16$ & $0.46 \pm 0.45$ \\
\hline Metabolic weight & $0.22 \pm 0.29$ & $-0.06 \pm 0.08$ & & $-0.20 \pm 0.16$ & -0.17 & $0.16 \pm 0.13$ & $0.27 \pm 0.33$ \\
\hline Feed conversion ratio & $0.70 \pm 0.22$ & $0.66 \pm 0.05$ & $0.85 \pm 0.05$ & $0.41 \pm 0.32$ & 0.69 & $0.64 \pm 0.10$ & $0.62 \pm 0.09$ \\
\hline Weaning weight & $0.34 \pm 0.34$ & $-0.45(0.22)^{\mathrm{B}}$ & & & & & \\
\hline Yearling weight & $0.15 \pm 0.28$ & $-0.26(0.14)^{\mathrm{B}}$ & $0.32 \pm 0.10$ & & & $0.19 \pm 0.15$ & \\
\hline Scrotal circumference & & $-0.03 \pm 0.11$ & & & 0.15 & & \\
\hline Yearling rib fat depth & & $0.17 \pm 0.05$ & & & 0.16 & & $0.35 \pm 0.30$ \\
\hline Yearling rib eye area & & $0.09 \pm 0.09$ & & & -0.17 & & $-0.52 \pm 0.32$ \\
\hline Yearling marbling score & & & & & -0.02 & & $0.32 \pm 0.29$ \\
\hline Carcass rib fat depth & & & & $0.48 \pm 0.12$ & & $0.27 \pm 0.20$ & $0.33 \pm 0.29$ \\
\hline Carcass rib eye area & & & & $-0.24 \pm 0.26$ & & $-0.45 \pm 0.29$ & $-0.64 \pm 0.26$ \\
\hline Intra-muscular fat & & & & $0.22 \pm 0.17$ & & & \\
\hline Carcass marbling score & & & & & & $-0.50 \pm 0.31$ & $0.28 \pm 0.38$ \\
\hline
\end{tabular}

ASources: 1. Herd \& Bishop (2000), 2. Arthur et al. (2001a), 3. Arthur et al. (2001b), 4. Robinson \& Oddy (2004), 5. Schenkel et al. (2004), 6. Hoque et al. (2006a,b), 7. Nkrumah et al. (2007a).

${ }^{B}$ Values in parentheses are maternal heritability estimates.

Available information tends to indicate that RFI is either not associated (Arthur et al., 2001a; Robinson \& Oddy, 2004) or very weakly associated (Hoque et al., 2006b) with rib eye area. However, the recent report by Nkrumah et al. (2007a) showed a low to moderate correlation between RFI and rib eye area, even after accounting for the high standard errors in their estimates. When measured ultrasonically in the live animal or directly on the carcass, rib fat depth tends to be weak to moderately associated with RFI. In the studies by Arthur et al. (2001a,b), weaner bulls and heifers were used, whereas in the study by Robinson \& Oddy (2004), 1 to 2 year-old feedlot steers were used. The results of these two studies suggest that the magnitude of the association is influenced by age, sex and diet of the test animals.

Information available on the genetic relationships between RFI and meat quality attributes is limited, and the results are conflicting. In the study with mixed breeds of temperate and tropically adapted cattle, Robinson \& Oddy (2004) reported a positive but weak genetic correlation between RFI and chemically extracted intramuscular fat, whereas in the study with Black Waygu steers, Hoque et al. (2006b) reported a negative but medium genetic correlation between RFI and marbling score.

\section{Selection response}

At the NSW Department of Primary Industries Research Centre at Trangie, Australia, Angus cattle have been selected for Low RFI and High RFI since 1994. Results from this study are presented in Table 3. After 5 years ( $\sim 2$ generations) of divergent selection, the responses indicates that selection for low RFI (high efficiency) resulted in progeny $(\mathrm{n}=62)$ that consumed less feed, were slightly leaner, but had similar performance, up to 1 year of age, compared to those $(\mathrm{n}=73)$ selected for high RFI.

A series of studies have been conducted with steers from the RFI selection lines on pasture. In these studies pasture intake was estimated using alkane markers (Hegarty et al., 2000). In a study with steers $(n=91)$ on medium quality pasture (ADG of 0.84 $\mathrm{kg}$ /day), Herd et al. (2004a) reported that initial and final liveweight of the steers, and feed intake, were not associated with variation in RFI estimated breeding values (EBV) of their sires. However, ADG tended $(\mathrm{P}<0.1)$ toward a favourable negative association with 
sire RFI EBV. The results show that $1 \mathrm{~kg} /$ day lower RFI EBV of a sire produced steer progeny that grew 19\% faster, with no increase in feed intake, had a $26 \%$ lower RFI, and a $41 \%$ better FCR. In another study (Herd et al., 2002), steer progeny $(n=51)$ of low and high RFI parents were evaluated during a dry summer period of low pasture availability which restricted ADG to 0.46 $\mathrm{kg} /$ day. Under those pasture conditions, Low RFI steers grew at $0.50 \mathrm{~kg} /$ day compared with $0.42 \mathrm{~kg} /$ day by high RFI steers (20\% faster), consumed $3.04 \mathrm{~kg} /$ day of pasture compared with $3.23 \mathrm{~kg} /$ day (6\% less) and had a FCR of 6.4:1 compared with 8.5:1 (25\% better). These results indicate that the independence between RFI and growth is valid only under ad libitum energy intake. Where feed energy intake is restricted, such as on medium to low quality pastures, steer progeny of low RFI parents grow faster relative to of high RFI parents. There is some evidence (Herd et al., 2004b) which points to the fact that low RFI steer have more efficient metabolic processes, hence they are able to meet their maintenance requirement with less energy intake than high RFI steers.

Using total tissue dissections of carcasses $(\mathrm{n}=33$ ) of steers divergently selected for RFI, Richardson et al. (2001) reported significant selection line differences in percent carcass fat but not in percent retail beef (Table 3). This confirms the presence of a weak genetic relationship between RFI and rib fat, as indicated by the genetic parameter estimates reported in Table 2.

After one generation of divergent selection for RFI, McDonaugh et al. (2001, Table 3) reported that there were no significant differences between the selection lines in the quality of meat from steers $(n=189)$, as assessed by shear force (a measure of meat tenderness). Using a subset of the meat samples $(n=71)$ it was observed that the selection line differences in calpain levels in meat tissues were not significant, however, meat tissue from Low RFI steers had higher calpastatin levels than that from High RFI steers, without any impact on tenderness.

The report by Arthur et al. (2005, Table 3) indicates that after 1.5 generations of divergent selection for postweaning RFI there were no significant selection line differences in maternal productivity of cows $(n=184)$ over three reproductive cycles, although indications are that the cows selected for low RFI cows may be achieving this level of productivity with a lower feed intake (Archer et al., 2002). In general, the expectations from the genetic parameters for RFI were confirmed by the responses in the RFI divergent selection lines, for all the traits studied.

\section{Summary of genetics}

Information to date indicates that postweaning RFI is moderately heritable, and that selection for low RFI will result in progeny that consume less feed for the same level of production as progeny of cattle selected for high RFI. Examination of available data under ad libitum feeding, suggests that, unlike FCR, RFI may not only be phenotypically independent of growth traits, but that the relationship may be genetically independent as well. There appears to be a weak genetic relationship between RFI and fatness traits but additional studies are required to accurately assess the magnitude of this relationship in different breeds, sexes, ages and feeding regimes. Genetic improvement in feed efficiency can be achieved by selection for low RFI and, in general, correlated responses in growth and other postweaning traits are expected to be minimal. There are gaps in our knowledge on the genetic relationships between RFI and meat attributes and maternal productivity. More research is required in these areas.

\section{Physiological basis for the variation in residual feed intake}

Most feed efficiency traits are correlated with production traits so it has been difficult to investigate the physiological mechanisms underlying variation in the efficiency of feed utilisation, independent of level of production. By definition, RFI is independent of level of production, hence a useful trait for studying the physiological mechanisms underlying variation in feed efficiency.

Herd et al. (2004b) reviewed published information across livestock species to come up with some potential physiological mechanisms by which variation in RFI may occur. Five major processes were identified, being those associated with intake of feed, digestion of feed, metabolism (anabolism and catabolism associated with and including variation in body composition), activity, and thermoregulation. Richardson \& Herd (2004) provided a synthesis of 
results of a series of experiments in cattle divergently selected for RFI, and estimated that heat production from metabolic processes, body composition and activity explained $73 \%$ of the variation in RFI. The proportion of variation in RFI that these processes explain, are: protein turnover, tissue metabolism and stress (37\%), digestibility (10\%), heat increment and fermentation (9\%), physical activity (9\%), body composition (5\%) and feeding patterns (2\%). The mechanisms responsible for over a quarter of the variation in RFI are still not known. Recent reports by Carstens et al. (2002), Basarab et al. (2003) and Nkrumah et al. (2006) confirm some of these results. The results in beef cattle are also confirmed by earlier studies in poultry. A review by Tixier-Boichard et al. (2002) identified heat production and body composition as the most important, and that the main source of variation in heat production appeared to be diet-induced thermogenesis and activity in poultry.

The physiological mechanisms identified so far are based on very few studies, some of which have small sample sizes. A challenge for the future is to unravel the mechanisms responsible for the unexplained variation and to validate their proportional contributions. The second challenge is to marry the physiological information with molecular genetics information which will become available in the future.

\section{Benefits from selection for residual feed intake}

\section{Economic benefit}

In assessing the potential economic benefit from selection for RFI, the focus should be on all phases of the production cycle, and not just on the growing animal phase. Archer et al. (2002) reported that, although postweaning RFI is highly correlated (genetically) with mature cow feed intake, it is only weakly correlated with other cow growth and body composition traits. A study by Arthur et al. (2005) reported no significant differences in maternal productivity in a herd of cattle divergently selected for postweaning RFI for 1 to 2.5 generations. These results indicate that economic assessment of the benefit in a whole production system context is likely to be easier when the feed efficiency trait used is RFI.
Using RFI as the model under a scenario where all young bulls are measured for feed intake, Archer \& Barwick (1999) concluded that for southern Australian beef production that targets the long-fed, premium Japanese market, incorporation of feed intake data in breeding schemes was profitable even at the highest cost of 450 Australian dollars (AUD) per animal, for the measurement of feed intake. For the domestic, grassfed market incorporation of feed intake data in breeding schemes was marginally profitable when measurement cost was AUD150 per animal, and not profitable at higher measurement cost. The high cost of measurement raises two issues. First, that in practice seedstock breeders will not measure feed intake of all their young male progeny, and that only those with superior genetic merit for the other economically important traits are likely to be measured. Secondly, that cheaper direct or indirect measures of feed intake and efficiency need to be developed. These issues highlight the need for the development of efficient breeding system design that includes two-stage selection using less expensive tests, such as gene markers, to choose a strategic sub-set of individuals in the herd to be measured for feed intake.

\section{The two-stage selection}

Three integrated long-term research projects on the genetics of feed efficiency in beef cattle have been in progress in Australia since 1992, as reported by Arthur et al. (2004). Data from these projects formed the basis of the following economic analyses.

The first analysis (Exton et al., 2000) modelled a 100-cow herd run on native pasture, with progeny being grown on improved pastures. In the production system modelled, surplus heifers were sold at 18 months of age into the domestic market and $80 \%$ of the steers were sold for feedlot finishing and subsequent sale as heavy export steers. Gross margin budget and cashflow analyses for this herd showed that, despite the initial cost of purchasing bulls genetically superior for feed efficiency, over a 25-year investment period, the internal rate of return was a healthy $61 \%$ and the net present value (NPV) of surplus income over expenses was AUD21907. This equates to an annual benefit per cow of AUD8.76. 
Table 3 - Least squares means ( \pm standard errors) for growth and feed efficiency traits, body composition, meat attributes and maternal productivity in beef cattle divergently selected for residual feed intake

\begin{tabular}{|c|c|c|c|c|}
\hline \multirow[b]{2}{*}{ Traits $^{\mathrm{a}}$} & \multirow{2}{*}{$\begin{array}{l}\text { Generations } \\
\text { of selection }\end{array}$} & \multicolumn{2}{|c|}{ Selection line } & \multirow[b]{2}{*}{ Significance } \\
\hline & & Low RFI & High RFI & \\
\hline Growth and feed efficiency & 2.0 & & & \\
\hline Weaning weight (kg) & & $232.5 \pm 3.1$ & $228.3 \pm 2.9$ & n.s. \\
\hline Average daily gain (kg) & & $1.44 \pm 0.03$ & $1.40 \pm 0.03$ & n.s. \\
\hline $12 / 13^{\text {th }}$ rib fat depth (mm) & & $5.3 \pm 0.2$ & $7.2 \pm 0.2$ & $*$ \\
\hline Rib eye area, $\left(\mathrm{cm}^{2}\right)$ & & $72.1 \pm 0.8$ & $74.2 \pm 0.7$ & n.s. \\
\hline Daily feed intake (kg) & & $9.4 \pm 0.3$ & $10.6 \pm 0.3$ & $*$ \\
\hline Feed conversion ratio & & $6.6 \pm 0.2$ & $7.8 \pm 0.2$ & * \\
\hline Residual feed intake (kg/day) & & $-0.54 \pm 0.12$ & $0.71 \pm 0.17$ & $*$ \\
\hline Body composition $^{A, \mathrm{~B}}$ & 1.0 & & & \\
\hline Internal organs (\%) & & $3.2 \pm 0.07$ & $3.1 \pm 0.04$ & n.s. \\
\hline External organs (\%) & & $13.3 \pm 0.15$ & $12.8 \pm 0.15$ & $*$ \\
\hline Non-carcass fat (\%) & & $7.8 \pm 0.35$ & $8.4 \pm 0.31$ & n.s. \\
\hline Carcass fat (\%) & & $9.9 \pm 0.39$ & $11.3 \pm 0.39$ & $*$ \\
\hline Retail beef (\%) & & $35.4 \pm 0.36$ & $35.2 \pm 0.49$ & n.s. \\
\hline Meat attributes ${ }^{C}$ & 1.0 & & & \\
\hline $12 / 13^{\text {th }}$ rib fat depth (mm) & & $9.2 \pm 0.3$ & $10.1 \pm 0.2$ & $*$ \\
\hline Shear force $(\mathrm{kg})$ & & & & \\
\hline Meat aged for 1 day & & $4.6 \pm 0.2$ & $4.6 \pm 0.2$ & n.s. \\
\hline Meat aged for 14 days & & $3.8 \pm 0.2$ & $3.5 \pm 0.2$ & n.s. \\
\hline m-Calpain (units/g tissue) & & $1.9 \pm 0.1$ & $1.8 \pm 0.1$ & n.s. \\
\hline $\mu$-Calpain (units/g tissue) & & $2.3 \pm 0.1$ & $2.1 \pm 0.1$ & n.s. \\
\hline Calpastatin (units/g tissue) & & $5.2 \pm 0.3$ & $4.6 \pm 0.3$ & $*$ \\
\hline Maternal productivity ${ }^{\mathrm{D}, \mathrm{E}}$ & 1.5 & & & \\
\hline Calving rate (\%) & & 89.2 & 88.3 & n.s. \\
\hline Weaning rate (\%) & & 81.5 & 80.2 & n.s. \\
\hline Milk yield (kg/day) & & $7.5 \pm 0.3$ & $7.8 \pm 0.3$ & n.s. \\
\hline Wt of calf weaned $(\mathrm{kg})$ & & $191.3 \pm 8.4$ & $198.4 \pm 7.7$ & n.s. \\
\hline
\end{tabular}

${ }^{\text {A }}$ Source: Richardson et al., 2001.

${ }^{B}$ As percentage of final liveweight.

CSource: McDonaugh et al., 2001

DSource: Arthur et al., 2005.

${ }^{E}$ Per cow exposed to bull.

* $P<0.05 ;$ n.s. $P>0.05$

In a second analysis, an evaluation of the benefit of recording RFI in industry breeding schemes using a model of investment and gene flow resulting from selection activities was conducted. The analysis considered breeding schemes targeting either the high quality Japanese export market (with steers fed for 210 days in the feedlot) or the grass fed domestic market. A base scenario was modelled where a range of criteria (without feed intake data) were used. A second scenario incorporated selection of sires for the breeding unit using a two-stage selection process, with a proportion of bulls selected after weaning for measurement of feed intake. After accounting for the cost of measuring feed intake (ranging from AUD150 to AUD450), additional profit was generated from inclusion of feed intake measurement on a proportion of bulls, for all the breeding schemes considered. Profit was generally maximised where $10 \%$ to $20 \%$ of bulls were selected at weaning for measurement of feed intake. Details of this analysis have been reported by Archer et al. (2004).

It should be noted that in all the economic analyses presented, the genetic selection applied was not for the single trait, RFI. It was evaluated in a multitrait selection index in representative genetic improvement schemes. The benefits presented are the marginal increase due to the inclusion of RFI and, therefore, it represents the additional benefits from genetic improvement in RFI. 


\section{Environmental benefit}

Most of the anticipated benefits from selection for RFI are economic in nature, but recent assessments indicate benefits in environmental sustainability. The agricultural sector is a source of greenhouse emissions worldwide, with the magnitude of its contribution differing from country to country. A recent FAO report estimates that globally livestock are responsible for 18 percent of greenhouse gas emissions (Steinfeld et al., 2006). Livestock produce methane and nitrous oxide, which are greenhouse gases with global warming potential 21 and 310 times greater than carbon dioxide, respectively (AGO, 2001). Methane is the major livestock greenhouse gas with the bulk being produced as a by-product of enteric fermentation in ruminants. Methane can also be produced, together with nitrous oxide from manure under certain management conditions, although the contribution from this source is minor (AGO, 2001). Recent studies have shown that selection for low RFI (high efficiency) cattle will reduce methane emissions by $15-30 \%$, and manure production by $15-20 \%$ relative to selection for high RFI (low efficiency) cattle (Nkrumah et al., 2006; Hegarty et al., 2007). The results from these studies highlight the potential and opportunity to use selection for reduced RFI as a greenhouse gas mitigation strategy. Recent Australian estimates (Alford et al., 2006), based on the results from the RFI selection lines, indicate that, for an individual adopting herd, the annual methane abatement in year 25 of selection was $15.9 \%$ lower than in year 1 . For the national herd, differential lags and limits to adoption were assumed for northern and southern Australia. The cumulative reduction in national emissions was 568,100 t of methane over 25 years, with annual emissions in year 25 being 3.1\% lower than in year 1. It was concluded that selection for reduced RFI will lead to substantial and lasting methane abatement, largely as a consequence of its implementation as a breeding objective for the grazing beef herd.

Secondly, selection for reduced RFI also allows feed intake to be reduced while maintaining the same level of production. For the grazing animal industries it translates to the utilization of less pasture biomass. This provides the farmer with flexibility to develop a property management plan that caters for both economic and environmental sustainability of the property. Strategies such as the preservation of the surplus biomass as hay or silage, planting of extra trees, or fencing off riparian zones, will not be at the expense of reduced animal productivity.

\section{Barriers to adoption}

Based on data from research stations and from industry, the Australian beef genetic improvement scheme, BREEDPLAN, started providing estimated breeding values (EBVs) for RFI (known as net feed intake, NFI, in the Australian beef industry) on animals in 2002 for the Angus and Hereford breeds. The level of adoption, however remains low, in spite of the fact that most economic analyses indicate positive return on investment. The major barriers to adoption include:

I. The high cost associated with identifying animals that are superior for reduced RFI. Equally important is the long period required for the investment in feed efficiency technology to return economic benefit. Additional analysis of the data presented by Exton et al. (2000) was carried out using the assumption that a bull genetically superior for RFI commands a AUD153 premium over a standard bull. The premium is equivalent to the amount required by the seedstock breeder to recoup the cost of testing elite candidate bulls in a two-stage selection program and paying AUD300 for the cost of measuring feed intake on each bull tested for RFI (Exton et al. 2000). The analysis showed a negative cash flow in the first 10 years of investing in superior feed efficiency genetics (Arthur \& Herd 2005). The period of negative cash flow is sensitive to the cost of the RFI test, and reduction in the cost will result in a reduction in the length of the negative cash flow period.

II. The general lack of appreciation in the beef industry of the importance of feed costs to enterprise profitability. This is especially important in the grazing industries, since most producers underestimate the true cost of pasture. 
III. The lack of accurate individual animal pasture intake measurement. Most of the research in feed efficiency has been done with prepared feeds as they are easier to deliver and measure. Feed intake at pasture is more difficult to measure.

IV. The practical limitations, animal health concerns and high overhead cost associated with centralised feed efficiency testing.

\section{Challenges for the future}

Simpler and inexpensive methods of identifying breeding animals that are superior for RFI need to be developed. Work on physiological markers for RFI started with a lot of promise after a study in Australia by Moore et al. (2005) indicated that plasma IGF-I was genetically correlated with RFI, and hence could be used as an indicator trait for RFI. After additional data were collected from industry herds, a re-analysis was done in 2006, which indicated that the genetic correlation was weaker, and that IGF-I was not an accurate predictor of genetic merit for RFI as previously thought (Johnston, unpublished).

Research into finding gene markers for RFI in beef cattle has intensified in the last five years. At the forefront of the gene marker search is the research by the Beef Cooperative Research Centre in Australia (a consortium of several research organizations) and by a consortium of organizations (including the University of Alberta) in Alberta, Canada. Both groups have identified QTL and SNPs that are associated with RFI, and are at various stages of validation and commercial release (Pitchford et al., 2002; Hayes et al., 2006; Barendse et al., 2007; Nkrumah et al., 2007b). Given the complexity of the physiological mechanisms underlying the variation in RFI (Herd et al., 2004b; Richardson et al., 2004), it is expected that a suite of gene markers will be required to explain a sizeable amount of the genetic variation in RFI.

\section{Literature Cited}

AUSTRALIAN GREENHOUSE OFFICE - AGO. Greenhouse emissions from beef cattle. Canberra: Australian Greenhouse Office, 2001.

ALFORD, A.R.; HEGARTY, R.S.; PARNELL, P.F. et al. The impact of breeding to reduce residual feed intake on enteric methane emissions from the Australian beef industry.
Australian Journal of Experimental Agriculture, v.45, p.985-993, 2005.

ARCHER, J.A.; ARTHUR, P.F.; HERD, R.M. et al. Optimum postweaning test for measurement of growth rate, feed intake and feed efficiency in British breed cattle. Journal of Animal Science, v.75 p.2024-2032, 1997.

ARCHER, J. A.; BARWICK, S. A. Economic analysis of net feed intake in industry breeding schemes. In: ASSOCIATION FOR THE ADVANCEMENT OF ANIMAL BREEDING AND GENETICS, 13, 1999, Bunbury. Proceedings... Bunbury: Association for the Advancement of Animal Breeding and Genetics, p.337-340, 1999.

ARCHER, J.A.; BARWICK, S.A.; GRASER, H-U. Economic evaluation of beef cattle breeding schemes incorporating performance testing of young bulls for feed intake. Australian Journal of Experimental Agriculture, v.44, p.393-404, 2004.

ARCHER, J.A.; REVERTER, A.; HERD, R.M. et al. Genetic variation in feed intake and efficiency of mature beef cows and relationships with postweaning measurements. In: WORLD CONGRESS ON GENETICS APPLIED TO LIVESTOCK PRODUCTION, 7., 2002, Montpellier. Proceedings... Montpellier: World Congress on Genetics Applied to Livestock Production, v.31, p.221-224, 2002.

ARCHER, J.A.; RICHARDSON, E.C.; HERD, R.M. et al. Potential for selection to improve efficiency of feed use in beef cattle: a review. Australian Journal of Agricultural Research, v. 50, p.147-161, 1999.

ARTHUR, P.F.; ARCHER, J.A.; HERD, R.M. Feed intake and efficiency in beef cattle: Overview of recent Australian research and challenges for the future. Australian Journal of Experimental Agriculture, v. 44, p.361-369, 2004.

ARTHUR, P.F.; ARCHER, J.A.; JOHNSTON, D.J. et al. Genetic and phenotypic variance and covariance components for feed intake, feed efficiency and other postweaning traits in Angus cattle. Journal of Animal Science, v.79, p.28052811, 2001a.

ARTHUR, P.F,; HERD, R.M. Efficiency of feed utilisation by livestock - Implications and benefits of genetic improvement. Canadian Journal of Animal Science, v.85, p281-290, 2005

ARTHUR, P.F.; HERD, R.M.; WILKINS, J.F. et al. Maternal productivity of Angus cows divergently selected for postweaning residual feed intake. Australian Journal of Experimental Agriculture, v.45, p.985-993, 2005.

ARTHUR, P.F.; RENAND, G.; KRAUSS, D. Genetic and phenotypic relationships among different measures of growth and feed efficiency in young Charolais bulls. Livestock Production Science, v.68, p.131-139, 2001b.

BARENDSE. W.; REVERTER, A.; BUNCH, R.J. et al. A validated whole-genome association study of efficient food conversion in cattle. Genetics, v.176, p.1893-1905, 2007.

BASARAB, J.A.; PRICE, M.A.; AALHUS, J.L. et al. Residual feed intake and body composition in young growing cattle. Canadian Journal of Animal Science, v.83, p.189-204, 2003.

BRELIN, B.; BRANNANG, E. Phenotypic and genetic variation in feed efficiency of growing cattle and their relationship with growth rate, carcass traits and metabolic efficiency. Swedish Journal of Agricultural Research, v.12, p.29-34, 1982.

CARSTENS, G.E.; THEIS, C.M.; WHITE, M.D. et al. Residual feed intake in beef steers: I. Correlations with performance traits and ultrasound measures of body composition. Journal of Animal Science, v.80, Suppl. 2, p.135, 2002. 
EXTON, S.C., HERD, R.M., DAVIES, L. et al. Commercial benefits to the beef industry from genetic improvement in net feed efficiency. Asian-Australasian Journal of Animal Science, v. 13, Suppl. B, p.338-341, 2000.

FITZHUGH Jr., H.A.; TAYLOR, S.C.S. Genetic analysis of degree of maturity. Journal of Animal Science, v.33, p717725, 1971.

HAYES, B.J.; CHAMBERLAIN, A.J.; GODDARD, M.E. Use of markers in linkage equilibrium with QTL in breeding programs. In: WORLD CONGRESS ON GENETICS APPLIED TO LIVESTOCK PRODUCTION, 8., 2006, Belo Horizonte. Proceedings... Belo Horizonte: World Congress on Genetics Applied to Livestock Production, 2006. Communication No., 30-06.

HEGARTY, R.S.; GOOPY, J.P.; HERD, R.M. et al. Cattle selected for lower residual feed intake have reduced daily methane production. Journal of Animal Science, v.85 p.1479-1486, 2007.

HEGARTY, R.S., SHAND, C., HARRIS, C. et al. Productivity and pasture intake of defaunated crossbred sheep flocks. Australian Journal of Experimental Agriculture, v.40, p.655-662, 2000.

HERD, R.M.; ARTHUR, P.F.; EXTON, S. Improving feed efficiency of animals in your herd. In: ANNUAL CONFERENCE OF THE GRASSLAND SOCIETY OF NSW INC., 2005, Tamworth, NSW Australia. Proceedings...Tamworth: Grassland Society of NSW Inc, 2005, p.57-62.

HERD, R.M.; BISHOP, S.C. Genetic variation in residual feed intake and its association with other production traits in British Hereford cattle. Livestock Production Science, v.63, p.111-119, 2000.

HERD, R.M.; HEGARTY, R.S.; DICKER, R.W. et al. Selection for residual feed intake improves feed conversion ratio on pasture. Animal Production Australia, v.24, p.85-88, 2002.

HERD, R.M.; DICKER, R.W.; LEE, G.J. et al. Steer growth and feed efficiency on pasture are favourably associated with genetic variation in sire net feed intake. Animal Production Australia, v.25, p.93-96, 2004a.

HERD, R.M.; ODDY, V.H.; RICHARDSON, E.C. Biological basis for variation in residual feed intake in beef cattle. 1 . Review of potential mechanisms. Australian Journal of Experimental Agriculture, v.44, p.423-430, 2004b.

HOQUE, M.A.; ARTHUR, P.F.; HIRAMOTO, K. et al. Genetic parameters for carcass traits of field progeny and their relationships with feed efficiency traits of their sire population for Japanese Black (Wagyu) cattle. Livestock Science, v.100, p.251-260, 2006b.

HOQUE, M.A.; ARTHUR, P.F.; HIRAMOTO, K. et al. Genetic relationship between different measures of feed efficiency and its component traits in Japanese Black (Wagyu) bulls. Livestock Science, v.99, p.111-118, 2006a.

KENNEDY, B.W.; van der WERF, J.H.J.; MEUWISSEN, T.H.E. Genetic and statistical properties of residual feed intake. Journal of Animal Science, v.71, p.3239-3250, 1993.

KOCH, R.M.; SWIGER, L.A.; CHAMBERS, D. et al. Efficiency of feed use in beef cattle. Journal of Animal Science, v.22, p.486-494, 1963

KORVER, S. Genetic aspects of feed intake and feed efficiency in dairy cattle: a review. Livestock Production Science, v.20, p.1-13, 1988.
MCDONAGH, M.B.; HERD, R.M.; RICHARDSON, E.C. et al. Meat quality and the calpain system of feedlot steers following a single generation of divergent selection for residual feed intake. Australian Journal of Experimental Agriculture, v.41, p.1013-1021, 2001.

MONTAÑO-BERMUDEZ, M.; NIELSEN, M.K.; DEUTSCHER, G.H. Energy requirements for maintenance of crossbred beef cattle with different genetic potential for milk. Journal of Animal Science, v.68, p.2279-2288, 1990.

MOORE, K.L.; JOHNSTON, D.J.; GRASER, H-U. Genetic and phenotypic relationships between insulin-like growth factorI (IGF-I) and net feed intake, fat and growth traits in Angus beef cattle. Australian Journal of Agricultural Research, v.56, p.211-218, 2005.

NATIONAL RESEARCH COUNCIL - NRC. Nutrient requirements for beef cattle, 7.ed. Washington, D.C.:National Academic Press, National Academy of Science, 1996

NKRUMAH, J.D.; BASARAB, J.A.; WANG, Z. et al. Genetic and phenotypic relationships of feed intake and measures of efficiency with growth and carcass merit of beef cattle. Journal of Animal Science, v.85, p.2711-2720, 2007a.

NKRUMAH, J.D.; OKINE, E.K.; MATHISON, G.W. et al. Relationships of feedlot feed efficiency, performance, and feeding behaviour with metabolic rate, methane production, and energy partitioning in beef cattle. Journal of Animal Science, v.85, p.145-153, 2006.

NKRUMAH, J.D.; SHERMAN, E.L.; LI, C. et al. Primary genome scan to identify putative quantitative trait loci for feedlot growth rate, feed intake, and feed efficiency of beef cattle. Journal of Animal Science, v.85, p.3170-3181, 2007b.

PITCHFORD, W.S.; FENTON, M.L.; KISTER, A.J. et al. QTL for feed intake and associated traits. In: WORLD CONGRESS ON GENETICS APPLIED TO LIVESTOCK PRODUCTION, 7., 2002, Montpellier. Proceedings... Montpellier: World Congress on Genetics Applied to Livestock Production, v.31, p.253-256, 2002.

RICHARDSON, E.C.; HERD, R.M. Biological basis for variation in residual feed intake in beef cattle. 2. Synthesis of results following divergent selection. Australian Journal of Experimental Agriculture, v.44, p.431-440, 2004.

RICHARDSON, E.C.; HERD,; R.M. ARCHER J.A. et al. Metabolic differences in Angus steers divergently selected for residual feed intake. Australian Journal of Experimental Agriculture, v.44, p.441-452, 2004.

RICHARDSON, E.C.; HERD, R.M.; ODDY, V.H. et al. Body composition and implications for heat production of Angus steer progeny of parents selected for and against residual feed intake. Australian Journal of Experimental Agriculture, v.41, p.1065-1072, 2001.

ROBINSON, D. L.; ODDY, V. H. Genetic parameters for feed efficiency, fatness, muscle area and feeding behaviour of feedlot finished beef cattle. Livestock Production Science, v.90, p.255-270, 2004.

SCHENKEL, F.S.; MILLER, S.P.; WILTON, J. W. Genetic parameters and breed differences for feed efficiency, growth, and body composition traits of young beef bulls. Canadian Journal of Animal Science, v.84, p.177-185, 2004. 
STEINFELD, H.; GERBER, P.; WASSENAAR, T. et al. Livestock's long shadow - Environmental issues and options. Food and Agriculture Organisation of the United Nations. Rome, 2006. 408p.

TIXIER-BOICHARD, M.; BORDAS, A.; RENAND, G. et al. Residual food consumption as a tool to unravel genetic components of food intake. In: WORLD CONGRESS ON
GENETICS APPLIED TO LIVESTOCK PRODUCTION, 7. 2002, Montpellier. Proceedings... Montpellier: World Congress on Genetics Applied to Livestock Production, v.31, p.213-220, 2002.

WANG, Z.; NKRUMAH, J. D.; LI, C. et al. Test duration for growth, feed intake, and feed efficiency in beef cattle using the GrowSafe System. Journal of Animal Science, v.84, p.2289-2298, 2006. 